\section{ATMOSPHERIC TIDES.}

$A \mathrm{~N}$ article on atmospheric tides, by $\mathrm{Mr}$. W. Krebs, who is a frequent contributor to the scientific literature of Germany, appears in Das Weltall, a Berlin journal of astronomy, of December, 1903. The author points out that the astronomer Mädler demonstrated in 1837 from the Berlin barometer observations the existence of an oscillation of air pressure in the course of a lunar day. The mean range exhibited a minimum pressure in the afternoon and a maximum in the forenoon of that period. This occurrence, which was found by. Mädler for the years $1820-1835$, was confirmed by Prof. Börnstein with reference to the years $1884-1888$, and was also shown to obtain at other German stations. But neither of these physicists ventured to affirm the existence of a tidal movement of the atmosphere in the oscillation which they had discovered.

The hitherto purely statical conception of the oscillations of air-pressure was an obstacle to such a theory. This conception supposed a maximum of pressure to be simply the result of an elevation, and a minimum to be the result of a depression of the barometric column. According to this still prevalent idea, a maximum of pressure must be expected at the time of the upper culmination, and a minimum at the time of the lower culmination of the moon. The former was, however, found to occur at Berlin almost exactly five lunar hours after the upper culmination, and the latter about the same time after the lower culmination. For these reasons Mädler thought it possible "that there was a third way in which the celestial bodies acted upon each other, which was still unknown to us," that is to say, other than by radiation and gravitation.

But the atmospheric oscillation in the course of a lunar day, first discovered by Mädler, appears to be nothing more than a wave caused by gravitation, when it is considered as a transverse oscillation and explained dynamically. The greatest rarefaction of the air occurs about half-way after the lower culmination, corresponding to the greatest uprising movement of the medium. The greatest compression of the air occurs about half-way after the upper culmination, corresponding to the greatest downward movement of the medium. In both cases an attraction of the moon on the lower atmosphere of the earth is presupposed. The third kind of mutual action between the celestial bodies assumed by Mädler accordingly reveals itself, in the case in question, as simply gravitation, when its effect is only considered from the standpoint of the wave theory. When applied to the solar day, the author considers that this view of the matter completes a missing link in the explanation of the double atmospheric oscillation according to Kelvin and Hann.

\section{ON LEAD POISONING AND WATER SUPPLIES.}

THE second volume on the above subject has recently been issued by the medical officer of the Local Government Board. The former volume contained information roncerning Dr. Houston's study of waters derived from moorland gathering grounds in Lancashire and Yorkshire the present volume gives details of an extensive series of laboratory experiments bearing on the general subject and conducted by Dr. Houston. They have been published in order to facilitate the interpretation of the results obtained when studying the solvent or erosive power of a water on lead pipes, with the view of counteracting these dangerous qualities. Particular attention is directed to observations on "standards" (p. 443) in this volume, where methods of measuring the solvent and erosive powers of a water upon lead are given enabling an opinion to be formed as to the degree of risk arising from the contact of such water with lead surfaces.

The report is illustrated with drawings of the apparatus employed in the investigations, and photographs have been reproduced to show the actual amount of deposit remaining in the tubes in which the erosion of lead by water had been allowed to take place.

From the nature of this report it will be understood that the substance of it consists of the tabulated results, together with brief descriptions of the experimental methods adopted. The main conclusions arrived at were stated in the previous volume, but a general summary of all conclusions is also given in Section iv. of this volume. A reference to this summary will be found useful to those who are concerned with the consideration of dangers of lead poisoning arising from water supplies.

The summary starts with an explanation of the meaning of the term "erosion," and proceeds to state that bright lead is rapidly eroded by rain and by snow water, as well as by distilled water; then follow the names of substances which do not influence the erosive power of water when introduced into it, as well as of substances which delay and inhibit the action. Moorland waters are next considered in regard to their erosive property, and the conditions which increase, diminish, or prevent their erosion are stated. Then follow waters which do not fall under the above classification, together with remedial measures which may be adopted to avoid danger. A similar classification and consideration of waters as regards plumbo-solvency is then shortly entered into, and, finally, the conclusions arrived at from chemical and bacteriological experiments as to the cause of acidity in moorland water are given. The summary terminates with a selection of conclusions which have already appeared in the former volume.

F. C.

\section{UNIVERSITY AND EDUCATIONAL \\ INTELLIGENCE.}

DR. H. H. Dixon has been elected professor of botany at Trinity College, Dublin, in succession to Dr. E. Percival Wright, who has resigned.

The Princess of Wales opened the new buildings of the St. Paul's Girls' School at Brook Green, London, W:, on April 15. Accommodation is provided for a museum, chemical laboratory, and practical physics.

At the request of the Board of Treasury the following gentlemen have consented to act as a committee to consider the allocation of the proposed increased grant to the university colleges giving education of a university standard in arts and science, viz. the Right Hon. R. B. Haldane, M.P. (chairman), Sir F. Mowatt, G.C.B., I.S.O., Mr. C. A Cripps, K.C., M.P., the Rev. Dr. Woods, late president of Trinity College, Oxford. Mr. Henry Higgs, of the Treasury, will act as secretary.

AN annual commemoration day was inaugurated at the University of Glasgow on Tuesday. Sir William Ramsay gave a discourse on Joseph Black's life and scientific work, and after the oration several honorary degrees were conferred. At the commemoration banquet on Tuesday evening Mr. Choate, the United States Ambassador, remarked in the course of a speech that the universities had to do their best for the guidance of the councils of the nations to which they belonged.

THE council for the extension of higher education in North Staffordshire has issued its report for 1903. I he objects of the council are to stimulate interest in higher education throughout the district, to assist in coordinating institutions and classes for higher and technical instruction, to aid existing institutions by the provision of supplementary and advanced courses of instruction, and to take steps for the establishment of a suitable institution in which to conduct a scheme of higher education for the benefit of the whole district. The report gives, among other information, reasons for the establishment as soon as possible of the proposed North Staffordshire University College, and urges the members of the council to join in the promotion of the scheme.

Trie United States consul at Leipzig has, says Science, compiled a table of the number of students attending twenty-one German universities during the winter 1903-4. The total number of matriculated students at these universities is 37,854 , of whom 3093 are foreigners, the largest number ever recorded. The number of foreign students is equivalent to 8.2 per cent. of the total number. Of other students attending lectures in these universities there are 7874 men and $13 \mathrm{I} 3$ women, so that the total number of students is $47,04 \mathrm{I}$. Noteworthy among other things in the 
table is the numerical preeminence of attendance at Berlin, where the total exceeds that of Munich, Leipzig, Bonn and Breslau combined. But 42 per cent. of Berlin's attendance is made up of non-matriculated students, representing a floating element to a considerable extent. Elsewhere in Germany this feature is a minor one in university attendance.

IN his presidential address at the annual conference of the National Association of Manual Training Teachers, held at Hastings on April 5, Sir John Cockburn dealt with the psychological importance of manual training. It is now recognised, said Sir John Cockburn, that the hand is one of the best channels to the intelligence, and that in training the hand we minister most effectually to the requirements of intellectual, moral, and physical development. Time in giving intellectual studies would be saved if half the school hours were spent in the workshop. Pupils detect their errors in actual work more readily than in abstract processes, and learn to despise inaccuracy and slovenliness. Nothing so clearly demonstrates the difference between right and wrong as manual training. A lie in wood stands selfexposed. The constructive imagination is strengthened, and invention is stimulated by manual work. Psychologists are agreed that in developing the mind manual training must rank as an indispensable element in all primary and secondary schools.

To celebrate the seventieth birthday of President Eliot, president of Harvard University, the graduates and students of the university have subscribed a thousand pounds for a portrait or bust to be placed in the Union. A very eulogistic letter with ten thousand signatures was presented to President Eliot on his birthday. After enumerating the distinguishing characteristics of his thirty-five years of presidency, the letter continues:- " Through you the American people have begun to see that a university is not a cloister for the recluse, but an expression of all that is best in the nation's thought and character. From Harvard University men go into every part of our national life. To Harvard University come from the common schools, through paths that have been broadened by your work, the youth who have the capacity and the will to profit by her teaching. Your influence is felt in the councils of the teachers and in the education of the youngest child.

Fearless, just, and wise, of deep and simple faith, serene in affliction, self-restrained in success, unsuspected by any man of self interest, you command the admiration of all men and the gratitude and loyalty of the sons of Harvard." British men of science will join in the congratulations to President Eliot that he has passed the age of seventy with undiminished power.

AT the ordinary meeting of the Society of Arts on April I3, Mr. J. C. Medd read a paper on agricultural education. He said it has now been realised that success in farming demands extensive scientific knowledge quite as much as thorough practical training. The development in the facilities for instruction since 1888 has been remarkable. Figures were quoted to show there had been a total outlay by the Government and by local authorities of nearly roo, oool. per annum. Mr. Medd thinks that it is to the evening school that the authorities must look for the improvement of the labourer and the recovery of the skilled or "handy" man. The paper concluded with a scheme to coordinate and place upon a satisfactory basis the rural and agricultural education of every county. Small village schools should be closed and their children conveyed daily to some central school. Better buildings and equipment, more regular attendance, and a more efficient staff would thus be ensured. A few favourably situated schools should be developed upon the model of the écoles primaires supérieures. A continuation school should be organised in every village. Winter schools of agriculture and horticulture should be established in selected districts according to the particular requirements and characteristics of each county, and the services of their directors should be made available for all farmers and gardeners during the summer. Demonstration plots should be placed in the charge of men who combined scientific accuracy with some actual knowledge of practical farming, and were in touch with the farmers of the district.

\section{SOCIETIES AND ACADEMIES.} LONDON.

Royal Society, March 17.--"Physical Constants at Low Temperatures. (I) The Densities of Solid Oxygen, Nitrogen, Hydrogen, \&c." By Prof. James Dewar, M.A., LL.D., D.Sc., F.R.S.

The observed densities of solid oxygen and nitrogen, taken at the boiling point of hydrogen, are $\mathrm{I} \cdot 425$ and $\mathrm{I} \cdot 026 \mathrm{re}-$
spectively. Similarly the density of solid hydrogen between $13^{\circ}$ and $14^{\circ}$ absolute was found to be 0.076 . From the observations given in the paper, the "Matthias Diameter Line "is deduced in each case, and from these the critical density and molecular volume at the zero of temperature follow. The molecular volume at zero of oxygen is $2 \mathrm{I} \cdot 2$, of nitrogen 25.5 , and of hydrogen 242 . From these results it follows that if solid water could result from a combination of solid hydrogen and oxygen taking place at the zero of temperature the reaction would in volve a volume contraction of 45 per cent. A discussion follows of the critical constants of hydrogen in which the want of agreement between theory and experiment is pointed out. The conclusion reached is that in the case of the constants of hydrogen a marked variation from what in the case of other substances may be regarded as fairly general results must be anticipated, and that further experiments are required to clear up the difficulties.

Linnean Society, April 7.-Prof. S. H. Vines, F.R.S., president, in the chair.-Mr. E. P. Stebbing exhibited lantern-slides of the metamorphoses of Clania Crameri, a Psychid moth from the Madras Presidency, showing its use of its food-plant, Casuarina equisetifolia, in the making of its protective case.-Mr. F. Enock displayed a series of more than fifty slides of natural colour photography of living insects and flowers by the Sanger-Shepherd threecolour prosess, the president adding a few remarks on the results.-Mr. C. E. Jones then gave an abstract of his paper, the morphology and anatomy of the stem of the genus Lycopodium.

Faraday Society, April 13--Mr. J. Swinburne, vicepresident, in the chair.-Alloys of copper and arsenic: Arthur J. Hiorns. The object of the author's investigations was to ascertain the exact relation between copper and arsenic in binary alloys, and the limit of proportion of arsenic that can be retained in copper in the cold solid state. The addition of arsenic lowers the melting point of copper uniformly down to about i4 per cent., when a steep fall in the freezing point curve occurs, reaching its lowest point at $685^{\circ} \mathrm{C}$. This alloy contains 19.2 per cent. of arsenic, which corresponds to the formula $\mathrm{Cu}_{5} \mathrm{As}_{2}$. The alloy with 22 per cent. of arsenic freezes at $708^{\circ}$, and the temperature gradually rises until the alloy with 28.34 is reached at $747^{\circ}$. This is the compound $\mathrm{Cu}_{3} \mathrm{As}$. At $810^{\circ}$ another chemical compound freezes, having the chemical formula $\mathrm{Cu}_{5} \mathrm{As}_{2}$; it contains 32.2 per cent. of arsenic. Beyond this point the temperature gradually falls again to a minimum at the alloy with about 35 per cent. of arsenic. The curve then rises to another summit at $740^{\circ}$, forming the compound $\mathrm{Cu}_{2} \mathrm{As}$, with $37 \cdot 24$ per cent. of arsenic. From this position the curve descends to $702^{\circ}$ with the alloy containing $4 I$ per cent. of arsenic ; this is nearly the practical limit of the direct combination of copper and arsenic.Experiments with a new primary cell : E. G. P. Bousfield. The cell consists of an inner porous pot containing nitric acid and a carbon pole, and an outer vessel containing sodium hydrate solution and a metal pole, preferably zinc, i.e. with a solution of from 12 per cent. to 15 per cent. ; using solutions of maximum conductivity with zinc and carbon poles on open circuit, an E.M.F. of 2.6 volts may be obtained. Not only does the cell possess this comparatively high E.M.F., but it may be short-circuited far longer than most cells before it runs down. A cell short-circuited through a total resistance of $0.6 \mathrm{r} \mathrm{ohm}$ gave a current of $4 \cdot 18$ amperes, which fell to $2.6 \mathrm{I}$ in an hour, 2.38 in $2 \frac{1}{4}$ hours, and $\mathrm{I} \cdot 75$ in 6 hours. A smaller cell gave a fairly constant current of about 0.8 ampere for 20 or 25 hours. Discharge curves are given in the paper.-Mr. Bousfield also contributed a note on determining accurately the percentage of ozone in gases not dissociated by moderate heat. 